\title{
Community Partnership Program: Mangrove Planting in the Coastal Area of Garassikang Village, Jeneponto Regency, South Sulawesi
}

\author{
Abdul Malik ${ }^{1}$, Abdul Rahim ${ }^{2}$, Ronald ${ }^{3}$, Andi Sitti Asmah4, Ulfah Syam ${ }^{5}$, Nur Hamdi ${ }^{1}$ \\ ${ }^{1}$ Department of Geography, Universitas Negeri Makassar \\ ${ }^{2}$ Department of Economics, Universitas Negeri Makassar \\ ${ }^{3}$ Village Community Empowerment Agency of Jeneponto Regency \\ ${ }^{4}$ Junior High School 1, Makassar \\ 5 Department of English Education Universitas Bosowa \\ E-mail: abdulmalik@unm.ac.id; abd.rahim@unm.ac.id; ronaldyaya8183@gmail.com; \\ ammazazy@gmail.com; ulfah.syam@universitasbosowa.ac.id; hamdigau@gmail.com
}

\section{Article History:}

Received: March 24th 2021

Revised: April 7th 2021

Accepted: May 30 2021

\section{Keywords:}

Community partnership program, mangrove, rehabilitation, planting, South Sulawesi.

\begin{abstract}
Aquaculture is one of the essential community livelihoods in Garassikang Village, West Bangkala District, Jeneponto Regency. However, abrasion that occurs in the coastal area of this village becomes a threat to the sustainability of community aquaculture ponds. The objectives of this Community Partnership Program (Program Kemitraan Masyarakat/PKM) is conduct a mangrove planting for preventing abrasion on the coast of Garassikang Village, Jeneponto Regency. We implemented the Community Based Research (CBR) method in socialization and mangrove planting services. A total of 1,500 mangrove seeds from Rhizophora sp. have been planted in this program and involve the government village and community as partners. The planting design giving a space for fishermen boat access. More attention of partners to maintain and conserve the mangrove planted become a worthy contribution to halt coastal abrasion and the sustainability of mangrove area and aquaculture activity in the coastal area of this village.
\end{abstract}




\section{Introduction}

Mangrove forest in Garassikang Village, Jeneponto Regency is one of these forest spots in South Sulawesi. However, the high intensity of aquaculture pond development without paying attention to the sustainability of mangroves, including not to remaining mangroves area as a green belt in the protection of their ponds, has a consequence to coastal abrasion in recent years ${ }^{1}$.

Mangrove loss can change significantly the pattern of sediment movements, and waves may begin to erode the coast. Besides, conversion to other land-uses such as aquaculture or agriculture can lead to the rapid breakdown of organic matter as oxygen becomes available in the soil, which in turn causes subsidence. The formerly stable or even advancing coasts can be withdrawing in many meters each year ${ }^{2}$. The clearing of mangrove areas into aquaculture ponds is triggering the main problems such as coastal abrasion. Several previous studies concluded that the vulnerability of mangroves throughout growth and succession processes can be used as a primary indicator of coastal disturbances ${ }^{3}$.
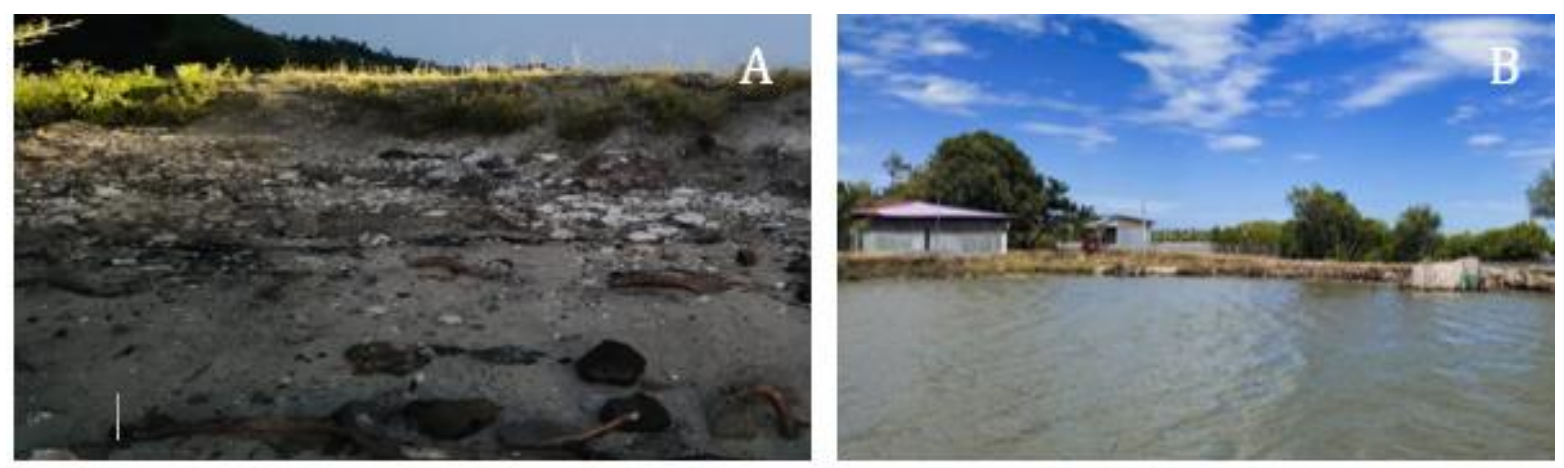

Figure 1. Coastal abrasion (A) and its location are very close to the aquaculture pond area (B) in Garassikang Village, Jeneponto Regency.

Abrasion has eroded the coastal area of this village and threatens the sustainable livelihoods of the community, especially the pond farmers in this village (Figure 1). Currently, the coastal area in Garassikang Village is one of the Jeneponto Regency coastal areas that has a high level of vulnerability to abrasion ${ }^{4}$.

\footnotetext{
${ }^{1}$ Malik, Abdul, and Abd. Rahim. Preliminary survey results for mangrove rehabilitation action in Garassikang Village Jeneponto Regency. Makassar: Universitas Negeri Makassar, May 2020.

2 Spalding, Mark, et al. "Mangroves for coastal defence. Guidelines for coastal managers and policy makers." Wetlands International and The Nature Conservancy (2014): 13-34.

${ }^{3}$ Nguyen, Linh Thuy My, Hanh Thi Hoang, Han Van Ta, and Pil Sun Park. "Comparison of Mangrove Stand Development on Accretion and Erosion Sites in Ca Mau, Vietnam." Forests 11.6 (2020): 615.

${ }^{4}$ Kadir, Abd. Kontur Geografi UNM penanaman mangrove di Jeneponto. 2016. https://makassar. antaranews.com/berita/77480/kontur-geografi-unm-penanaman-mangrove-di-jeneponto. Accessed on 5 November 2020.
} 
Given these critical issues, the purpose of the Community Partnership Program (Program Kemitraan Masyarakat/PKM) is to rehabilitate the mangrove area of Garassikang Village, Jeneponto Regency for preventing coastal abrasion that threatens community aquaculture pond areas through planting activity.

The area of mangrove planting activity as a target of this Community Partnership Program lies at latitude $5^{\circ} 33^{\prime} 35.79^{\prime S}$ and longitude $119^{\circ} 31^{\prime} 2.17^{\prime \prime E}$. The distance of the location from Universitas Negeri Makassar, Makassar City is about $58.06 \mathrm{~km}$ (Figure 2) and $42 \mathrm{~km}$ from Bontosunggu, Capital of Jeneponto Regency. The total population of this village was 2248 people in 2018, and most of them were working as fishermen and shrimp farmers. This village is a mainstay village from the fishery's sector, especially from aquaculture in the West Bangkala District ${ }^{5}$.

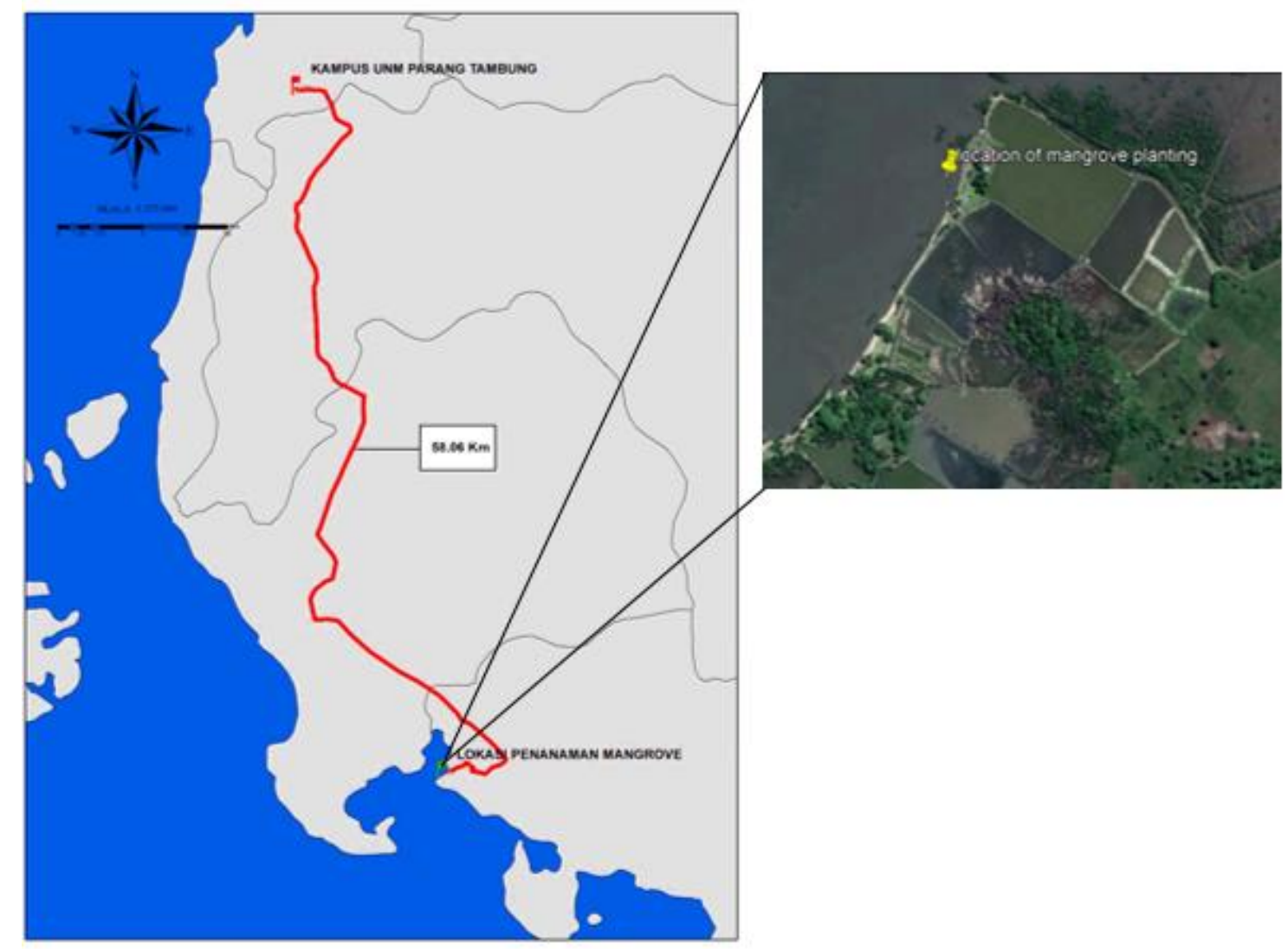

Figure 2. Location of mangrove planting in Garassikang Village, Jeneponto Regency.

${ }^{5}$ BPS Kabupaten Jeneponto. “Kecamatan Bangkala Barat dalam Angka 2019”. Badan Pusat Statistik Kabupaten Jeneponto (2019). 


\section{Method}

The implementation of the Community Partnership Program used the Community Based Research (CBR) method. CBR is an approach used to develop a partnership between practitioners and community members to address complex social problems for the betterment of society. The subjects of this service are community members of Garassikang Village, Jeneponto Regency.

The stages of the Community Partnership Program activities carried out are explained through the diagram below (Figure 3):

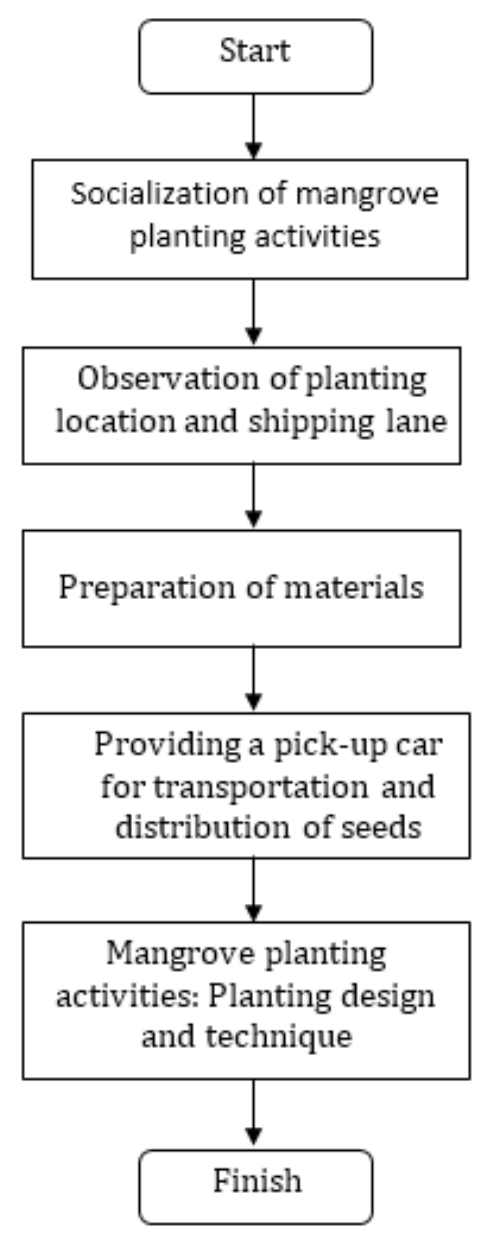

Figure 3. Flow diagram of Community Service Program

This activity started by analyzing the situation related to the issue of mangrove utilization and its impacts. In this service activity, the selection of a partner village (Garassikang Village, Jeneponto Regency) because along the coast of this village has experienced abrasion that threatens the livelihoods and lives of the community. Furthermore, the head of the implementer made a correspondence and discussion with the head of Garassikang Village regarding the plan of service activities, with the following 
stages of activity (Figure 3):

1. Socialization of mangrove planting activities

Socialization activity was conducted by distributing the socialization materials to the local Village Heads to be distributed to other communities.

2. Observation of planting location and the shipping lane

Initial observations were made by observing the prevailing tidal regime, sediment types, and observing the types of mangroves remaining in the rehabilitation site. We also discussed with the Village Head and a few communities as partners regarding fishing boat routes to avoid conflict of interest.

3. Preparation of materials

We prepared materials, such as cement shovels, seed dibber (called Tugal), wooden stakes, tape measure, and plastic rope (called Rapia rope) for planting. For the mangrove seed, we provided a total of 1,500 mangrove seeds from species of Rhizophora sp. that were obtained from mangrove nurseries in Tongke-Tongke Village, Sinjai Regency. The mangrove seeds taken are healthy, fresh, free from pests and diseases.

4. Provide a pick-up car for transportation and distribution of seeds

All of the mangrove seeds taken from the nursery in Tongke-Tongke Sinjai Village were transported by pick-up car to the planting location (Figure 4). Furthermore, mangrove seeds are stored, placed, and arranged in such a way that they are neatly arranged near the planting location.

5. Mangrove planting activities: Planting design and technique

- Planting design

Before planting, cleaning the planting location is carried out from disturbing vegetation. Then a planting path was made using a tape measure and Rapia rope in the knots with a distance of one meter from each other. The purpose of the knots on the Rapia rope is to make it easier to find out where to dig holes and where the seeds will be planted and to uniform the spacing $(1 \mathrm{~m} \times 1 \mathrm{~m})$. This spacing is intended so that it is not mixed and does not change the natural nature of mangroves, namely forming pure stands.

- Planting Technique

Planting begins by making a hole using a Tugal and cement spoon with a hole depth that is twice the high of the polybag, and the area is larger than the polybag area. Furthermore, mangrove seedlings are planted vertically into the hole by covered with soils without the need to remove the seeds from the polybag. 


\section{Results}

\section{Socialization of mangrove planting activities}

Socialization activities involving partners cannot be carried out perfectly, because this village and others village in Jeneponto Regency are hampered by the prohibition of holding mass gathering activities in order to prevent the spread of Covid-19. The Jeneponto Regency is one of the regencies designated as a red zone for the spread of Covid-19 in South Sulawesi. The socialization by teleconference method cannot be carried out, because it is constrained by partners' understanding of this technology and the lack of facilities owned by partners. Therefore, the implementers only by distributed the socialization materials to the local Village Heads to be distributed to other communities.

\section{Mangrove Planting Activity}

In the implementation of this activity, the contribution of partners can be seen starting from observing planting locations, sharing information related to the preparation and mangrove planting activity.

The mangrove planting activity that conducted in July 2020 was planted a total of 1500 mangrove seeds from Rhizophora sp. in the coastal area of Garassikang village, Jeneponto Regency for protection, and reduction of coastal abrasion that threatens community aquaculture ponds. According to figure 4, mangrove planting area was divided into two sides with separate shipping lanes for boat access of fishermen. In addition, this figure 4 also show two sides (left and right sides) mangrove planting areas before and after planting conducted.

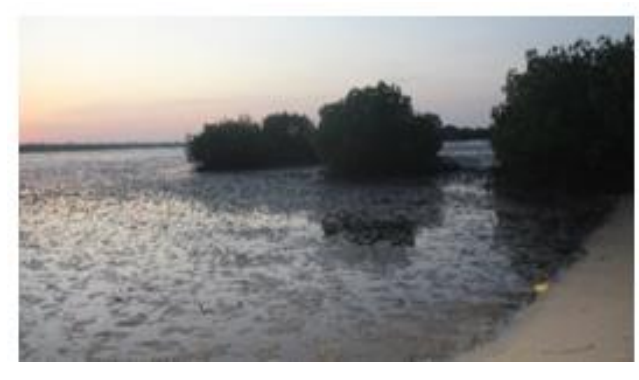

Before planting (right side)

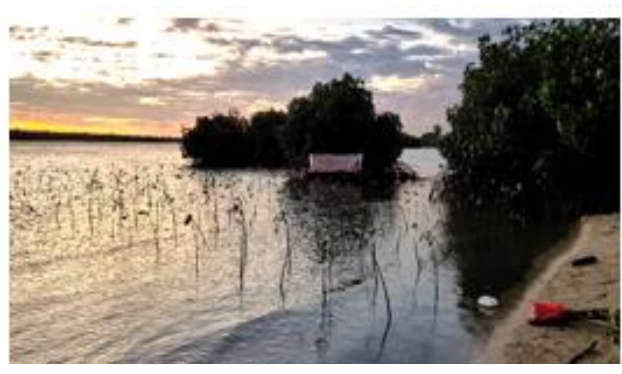

After planting (right side) 


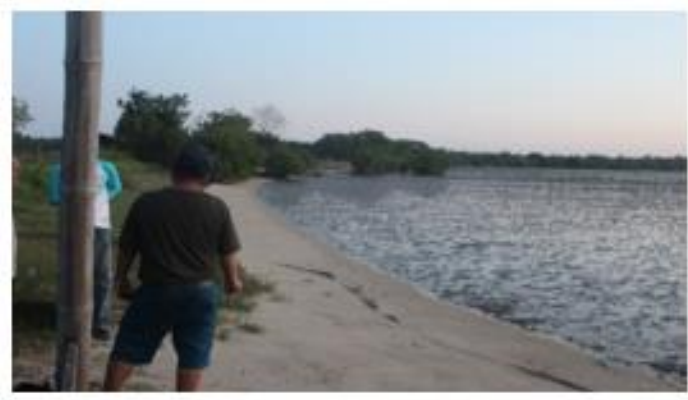

Before planting (left side)

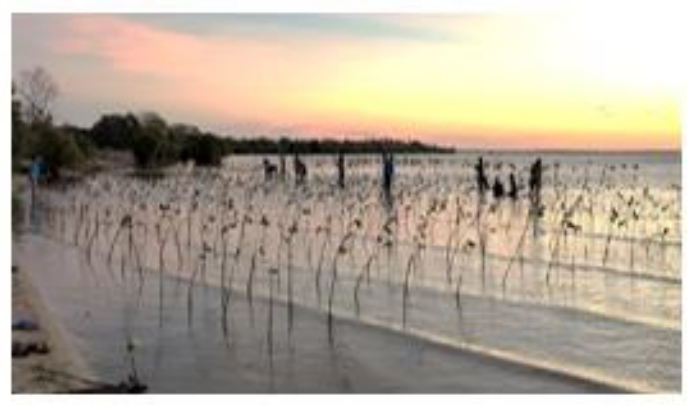

After planting (left side)

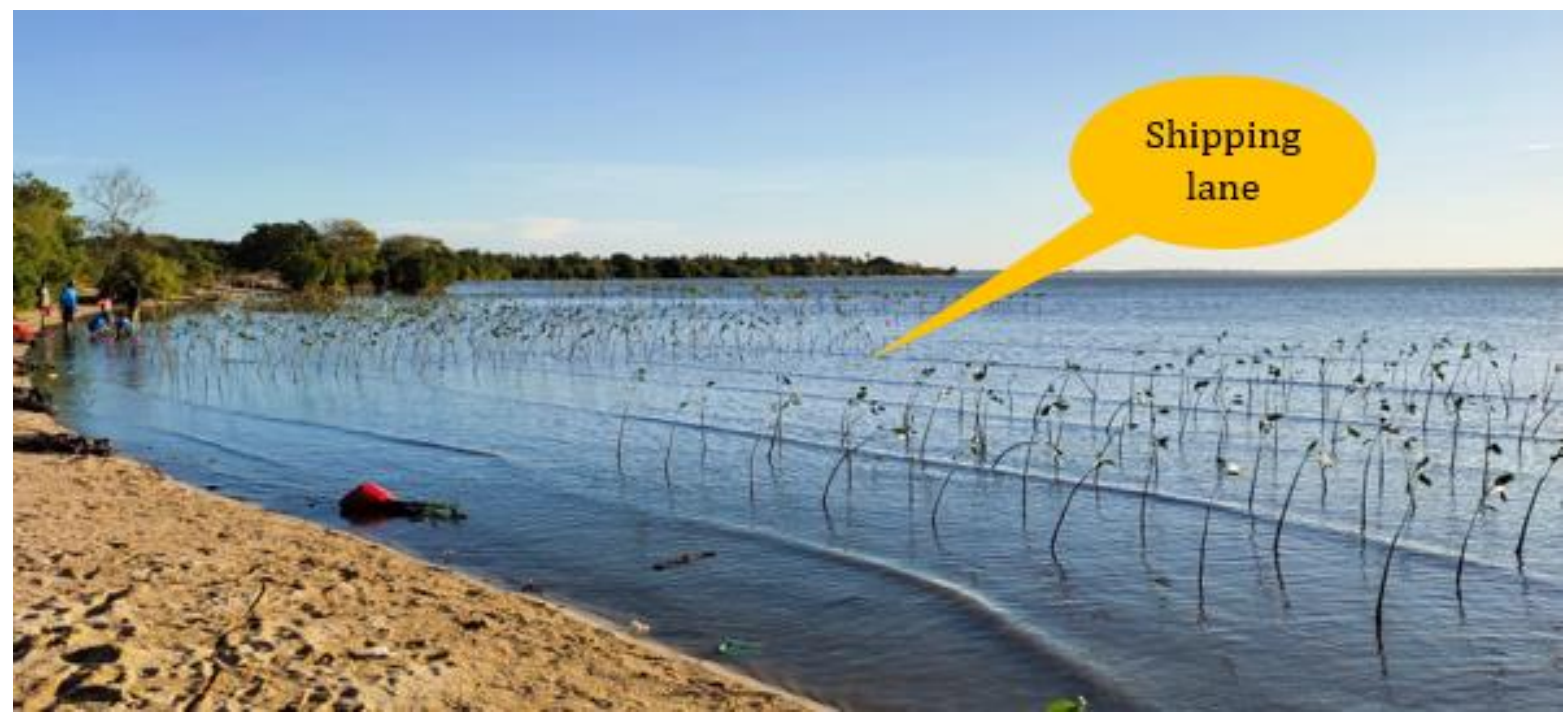

Figure 4. Condition of the coastal area, before and after mangrove planting activity and shipping lane in Garassikang Village, Jeneponto Regency

Mangrove planting activities in Garassikang Village, Jeneponto Regency provides benefit in protection and prevent coast from abrasion due to scouring by sea waves, especially in the West Monsoon which is marked by stronger winds and higher sea wave heights and speeds. At the same time, it also provides protection for the pond area which is located not far from or behind the shoreline (the distance from the shoreline is only 3 15 meters), so that economic losses and loss of community livelihoods can be avoided.

\section{Discussion}

Mangrove rehabilitation actions are essential in Indonesia, include in South Sulawesi, mainly as the consequences of mangrove degradation and deforestation apparent in the form of coastal abrasion and loss of coastal fisheries productivity, such as 
loss of aquaculture pond 6 .

A total of 1500 Rhizophora sp. seeds in this planting activity were selected due to this species has strong roots that can reduce incoming wave energy and height through reflection and dissipation by as much as $71 \%{ }^{7}$. This species is suitable with the sandy clay sediments which dominated in this area and have the high capability through its stilt roots to trap sediment in the accretion process, ${ }^{8}$. Stilt mangrove forests and mangroves play an important role in the protection of coastlines, aquaculture ponds, and other coastal infrastructure. In Kalibo Bakhawan Eco Park, the Philippines, stilt mangroves are planted for coastal or fishpond protection ${ }^{9}$.

The planting action was involved the government village and community as the partners, and some university students from the Department of Geography Universitas Negeri Makassar to assist this activity. To assist the local community in fulfilling their role, a socialization about mangrove use and how to plant mangrove seeds has been given. However, this socialization was conducted just by sharing the material with to head of the government village and some of the local communities. It is due to the issue of Covid-19 which prohibits holding meetings that involve many people. Furthermore, the communities are encouraged in the maintenance of mangroves after the plantation for the effective growth of mangrove planted and protection of the sustainability of mangrove area for aquaculture activity in this village. Participation of local community in in planning and monitoring mangrove rehabilitated are is mostly important for sustainability of mangrove area ${ }^{10}$.

\section{Conclusion}

Through this community partnership program, several things have been achieved, firstly, despite the socialization activity for increasing community knowledge about mangrove use and mangrove planting just by sharing the material with to head of the government village and some of the local communities due to the Covid-19 issue, but some of the local community with their awareness have involved their self in mangrove planting activity. Secondly, the coastal area in this village has planted 1500 mangrove

${ }^{6}$ Kusmana, Cecep. "Lesson learned from mangrove rehabilitation program in Indonesia." Jurnal Pengelolaan Sumberdaya Alam dan Lingkungan (Journal of Natural Resources and Environmental Management) 7.1 (2017): 89-97.

${ }^{7}$ Brinkman, Richard Michael. Wave attenuation in mangrove forests: an investigation through field and theoretical studies. Diss. James Cook University, 2006.

8 Duke, Norman C. "Indo-West Pacific stilt mangroves: Rhizophora apiculata, R. mucronata, R. stylosa, R. X annamalai, R. X lamarckii." Permanent Agriculture Resources (PAR), 2006. 641-660.

9 Duke, Norman C. "Indo-West Pacific stilt mangroves: Rhizophora apiculata, R. mucronata, R. stylosa, R. X annamalai, R. X lamarckii." Permanent Agriculture Resources (PAR), 2006. 641-660.

${ }^{10}$ Camacho, Leni D., et al. "Sustainable mangrove rehabilitation: Lessons and insights from community-based management in the Philippines and Myanmar." APN Science Bulletin (2020). 
seeds from Rhizophora sp. for protecting the coastal area and aquaculture ponds of the community from abrasion damage, so that economic losses and loss of community livelihoods can be avoided. However, Local government and community need to maintain and protect mangroves have been planted for the success rate of mangrove growth and can be prevented the coastal area from further abrasion events.

\section{Acknowledgements}

We thank the Directorate of Research and Community Service, Ministry of Research, Technology, and Higher Education Indonesia for funding this program. We thank the Institution of Research and Community Service (LP2M) Universitas Negeri Makassar for facilitating this program. We also thank the Government of the Jeneponto Regency, especially for The Government of Garassikang Village, Department of Geography Universitas Negeri Makassar, and Kontur Geografi Universitas Negeri Makassar for supporting this program.

\section{References}

BPS Kabupaten Jeneponto. “Kecamatan Bangkala Barat dalam Angka 2019”. Badan Pusat Statistik Kabupaten Jeneponto (2019).

Brinkman, Richard Michael. Wave attenuation in mangrove forests: an investigation through field and theoretical studies. Diss. James Cook University, 2006.

Camacho, Leni D., et al. "Sustainable mangrove rehabilitation: Lessons and insights from community-based management in the Philippines and Myanmar." APN Science Bulletin (2020).

Duke, Norman C. "Indo-West Pacific stilt mangroves: Rhizophora apiculata, R. mucronata, R. stylosa, R. X annamalai, R. X lamarckii." Permanent Agriculture Resources (PAR), 2006. 641-660.

Kadir, Abd. Kontur Geografi UNM penanaman mangrove di Jeneponto. 2016. https://makassar. antaranews.com/berita/77480/kontur-geografi-unmpenanaman-mangrove-di-jeneponto. Accessed on 5 November 2020.

Kusmana, Cecep. "Lesson learned from mangrove rehabilitation program in Indonesia." Jurnal Pengelolaan Sumberdaya Alam dan Lingkungan (Journal of Natural Resources and Environmental Management) 7.1 (2017): 89-97.

Malik, Abdul, and Abd. Rahim. Preliminary survey results for mangrove rehabilitation action in Garassikang Village Jeneponto Regency. Makassar: Universitas Negeri Makassar, May 2020.

Nguyen, Linh Thuy My, Hanh Thi Hoang, Han Van Ta, and Pil Sun Park. "Comparison of 
Mangrove Stand Development on Accretion and Erosion Sites in $\mathrm{Ca} \mathrm{Mau,}$ Vietnam." Forests 11.6 (2020): 615.

Spalding, Mark, et al. "Mangroves for coastal defence. Guidelines for coastal managers and policy makers." Wetlands International and The Nature Conservancy (2014): 13-34.

Wahyuni, E. S., Mubarok, H., Budiman, F. N., \& Pratomo, S. W. "Pemanfaatan Energi Terbarukan untuk Pembangkit Listrik Tenaga Surya Berbasis Komunitas: Menuju Desa Mandiri Energi". Engagement: Jurnal Pengabdian Kepada Masyarakat, 4.2 (2020): 493-508. 